\title{
TRUE BELIEVERS: THE RECEPTION OF DESCARTES'S MEDITATIONS BY MALEBRANCHE AND HUET
}

\author{
D. Anthony Larivière* and Thomas M. Lennon**
}

\begin{abstract}
RESUMO Tanto Nicholas Malebranche como Pierre-Daniel Huet foram inicialmente positivamente influenciados pelas Meditações de Descartes e ambos terminaram por perceber falhas nesta obra. No que concerne o dualismo mente e corpo, Malebranche buscou fortalecer a posição cartesiana abandonando o critério de clareza e distinção em favor de um princípio de intencionalidade. Huet abandonou o cartesianismo como um todo em favor do ceticismo. A fonte destas respostas diversas está nas avaliações distintas que fizeram da integridade de Descartes.
\end{abstract}

ABSTRACT Both Nicholas Malebranche and Pierre-Daniel Huet were at first positively influenced by Descartes's Meditations, and both came to perceive shortcomings in that work. With respect to mind-body dualism, Malebranche attempted to strengthen Descartes's position by jettisoning clarity and distinctness basing it instead on a principle of intentionality. Huet jettisoned the whole position in favor of skepticism. The source of their different responses lay in their different estimations of Descartes's integrity.

Palavras-chave: Malebranche, Huet, Descartes, skepticism, dualism, intentionality, dissimulation, clarity and distinctness, Cartesianism, Christian philosophy.

* Lakehead University, Ontario, Canada.

** University of Western Ontario, Canada.

KRITERION, Belo Horizonte, $\mathrm{n}^{\circ}$ 106, Dez/2002, p.89-107 
Reception of a philosophical work is of interest, obviously, only when there is engagement with it. One form of engagement is when the work is accepted and then extended in terms of its own principles; another form is when the work is initially accepted and then rejected. Each of these forms of reception is to be found in the seventeenth century with respect to Descartes's Meditations, most dramatically in the cases of Nicolas Malebranche and Pierre-Daniel Huet. Both drank very deeply from the cup, so to speak, and had an appreciation for Descartes's philosophy which was rather more profound than that of many of their contemporaries. Yet it would be hard to find two more diametrically-opposed views on the worth of the Meditations. While Malebranche remained throughout his life fundamentally a Cartesian, elucidating, extending and even emending the Meditations, Huet abandoned Cartesianism altogether, and became, like many a reformed addict, one of its bitterest opponents.

Our story here therefore involves two diverging paths, one positive and constructive, one negative and destructive, each of which had a part to play, if not directly then at least by way of reflection, in the reception that Descartes's Meditations received in the early modern period. Yet there is more of interest in Malebranche and Huet than simply how it is that Descartes's seminal work could have met with reactions so opposed to one another. For both Malebranche and Huet, (and, if one accepts his own account, even for Descartes himself, ) the real measure of the worth of a philosophical system is its consequences for religion. In this respect, both Malebranche and Huet remained in the grip of the traditional view of philosophy as the handmaiden of theology. Both men were deeply religious, and both took up the cause of Cartesianism, at least in part, because of its perceived relation to Christianity. Therefore, as opposed philosophically as Malebranche and Huet became, they were united by the fervor of true belief. And as true believers, they viewed Descartes as either prophet or demon, and his works, especially the Meditations, as either inspired or pernicious. The upshot was that Malebranche continued to be a true believer in Cartesianism, whereas Huet rejected Cartesianism and became a skeptic while remaining a true believer in what was for him the more important cause, namely Christianity.

At the basis of this radical divergence was a moral issue. For Malebranche, such few errors as Descartes might have made are cognitive or logical, and as such remediable. For Huet, Descartes's cognitive or logical errors spring from a moral failing on his part and are thus beyond repair. For him, Descartes is an intellectual cheat, acting out of motives of pride, arrogance, and vanity. Worst of all, he cheats on the very issues that he himself identified as motivating the Meditations, viz. proofs of the existence of God and of 
the immortality of the soul based on its real distinction from the body. For Malebranche, on the other hand, these two issues are the prime examples of Cartesian views that can be elucidated and emended on Descartes's own grounds. In this paper, therefore, the very different receptions of Descartes by Malebranche and Huet will be focused on these two issues.

As the best-known, and most influential of Descartes's disciples in the seventeenth century, Nicolas Malebranche (1638-1715) was a relatively late convert to Cartesianism. The turning point, according to his biographer André, was the discovery of The Treatise on Man in 1664. ${ }^{1}$ Descartes's physiological treatise had only just been published in French for the first time that year, though the core works upon which Descartes's reputation had been founded - the Discourse, the Meditations, and the Principles - had seen wide circulation for the twenty years previous. André's description of Malebranche's reaction to the treatise makes it sound very much like a religious conversion: "I know of no better way of expressing the impression which he felt than by reporting what he himself often recounted to his friends: the joy of learning such a great number of new discoveries gave him such violent heart palpitations that he was obliged to leave off reading to catch his breath." 2

We have no reason to doubt the accuracy of André's description, and the constancy of Malebranche's devotion to Cartesian principles throughout the remainder of his life bespeaks a deep attachment. On the other hand, it may be doubted that it was Descartes's mechanical picture of the human body which first inspired this devotion. André indicates that Malebranche moved quickly from The Treatise on Man to a study of the three core works mentioned above, and that within a short period of time Malebranche had mastered the Cartesian philosophy: "He devoted three or four years to this study, meditating more often than reading. And by this means he became so much a master of Descartes's philosophy that, thirty years later, it remained at his fingertips, and he could respond in a flash whether this or that thing was or was not so; by recalling the principles he saw immediately the consequences by the least effort of mind". 3

The time period mentioned here certainly makes it seem that Malebranche had his conversion experience while reading L'Homme, supposing that his heart palpitations did not persist for a period of years. But Ferdinand Alquié discusses the edition which Malebranche read in 1664, and says that 
"this edition includes the Description of the Human Body, whose preface places great emphasis on the distinction between mind and body. It contains as well texts by Clerselier, Louis de La Forge, and Schuyl, which reveal to the reader Descartes's philosophy as a whole." 4 The edition referred to here is doubtless the first French edition. As Alquié rightly points out, this edition contains a preface by Schuyl (indeed, it is the very same preface which had appeared in the first Latin edition of 1662), the "Epistre à Monsieur de Colbert" by Clerselier, The Treatise on Man and De la formation du foetus by Descartes, and a concluding section by Louis de La Forge — a fairly substantial section at that; Descartes's texts run to one-hundred and seventy pages, La Forge's text to two-hundred and thirty-seven. ${ }^{5}$ So Alquié is quite correct to say that the text which André says was suggested to Malebranche by a bookseller that day on the quai des Augustins was more than simply a physiological treatise, but rather an epitome of the Cartesian philosophy for which the embedded treatises served as examples. But more than this, Malebranche's conversion came about as the result of reading a text which laid out a coherent and grandiose scheme for the wholesale replacement of the Scholastic-Aristotelian tradition of learning. It was this in all likelihood which was the cause of his racing heart.

Despite the fact that Malebranche came to Cartesianism via the back door, so to speak, it is nevertheless true that the Meditations was the foundation of his allegiance to Cartesianism. The culmination of the period of study which André mentions was the Search After Truth, for if André is correct about this time frame, this work was begun just as Malebranche's period of meditation was ending, and he cannot fail to have been deeply under Descartes's influence. ${ }^{6}$ The Search is Malebranche's most extensive and exhaustive exposition of his philosophical thought and also the most accurate in the sense that in its six editions (1674-75 to 1712) spanning his career Malebranche incorporated the alterations, refinements, and additions occasioned by his polemics with a number of people on a number of topics. This is reason enough to treat the Search as our best source for tracing the debt which Malebranche owed to the Meditations.

The references to Descartes, and to the Meditations particularly, in the

4 Ferdinand Alquié, Le Cartésianisme de Malebranche (Paris: J. Vrin, 1974), p. 25.

5 The full title of the editions is: L'Homme De Rene Descartes Et Un Traité De La Foetus Du Mesme Autheur Avec les Remarques de Louys de La Forge, Docteur en Medicine, demeurant à la Fleche, Sur le Traitté de l'Homme de Rene Descartes \& sur les Figures par luy inventées. See A. J. Guibert, Bilbiographie des oeuvres de René Descartes publiées au XVIle siècle (Paris: Éditions du Centre National de la Recherche Scientifique, 1976) for information on this and other editions which appeared in the seventeenth century.

6 André dates the beginning of the Search as 1668. 
Search are few. ${ }^{7}$ Yet one cannot read too much into the sparsity of citation, for it was to be some time yet before any author felt it to be his duty to scrupulously acknowledge his sources. Those references which do occur, however, show clearly how the Meditations influenced Malebranche's own system. ${ }^{8}$ This influence is the source of Malebranche's insistance upon the absolutely fundamental nature of the distinction between soul and body, and the principal attributes which distinguish them: thought and extension. ${ }^{9}$ The earliest citation of the Meditations in the Search, for instance, is in the context of the distinction between soul and body in Chapter ten of Book one. Indeed all of the references which can certainly be traced to the Meditations occur either very early in the Search or in the Elucidations which were added as appendices, beginning with the third edition (1677-78).

It will become clear in what follows here both that Malebranche took the real distinction between soul or mind and body to be critical for his Cartesianism, and that the justification of this distinction was to be found for him in the Meditations. Indeed, the acceptance of the distinction between mind and body, the usefulness of that distinction for detailing the sources of error and a method for avoiding it, and, as will be argued below, an extension of Descartes's argument from the Meditations for establishing that distinction, are among the unequivocally Cartesian elements of Malebranche's philosophy. Let us turn, therefore, to Descartes's argument.

In the sixth Meditation, Descartes gives what he takes to be a proof of the real distinction between mind and body. His argument goes as follows: "the fact that I can clearly and distinctly understand one thing apart from another is enough to make me certain that the two things are distinct, since they are capable of being separated, at least by God." ${ }^{10}$ He draws this inference from the premise that "everything which I clearly and distinctly understand is capable of being created by God so as to correspond exactly with my understanding of it." Descartes seems to be appealing to the clarity and distinctness rule introduced in the third Meditation - "whatever I perceive

7 There are few, that is, given that Descartes is the obvious inspiration of the Search. On the other hand, it must be noted that, aside from Augustine, Descartes is the author most frequently cited by Malebranche.

8 In the Search, at least, Malebranche mentions the Correspondence, the Dioptrics, the Geometry, The Treatise on Man, the Passions, and the Principles, as well as the Meditations. The Principles is the most frequently cited work there, but almost always in the context of some issue in natural philosophy. In the context of Malebranche's foundational metaphysics and ontology, the Meditations is the Cartesian work most frequently appealed to.

9 The first of these is derived from Meditation VI, the second from Meditation IV.

10 References to the Meditations are to the Cottingham et al. translation, The Philosophical Writings of Descartes (Cambridge: University Press, 1984-85), hereafter referred to as CSM, and will be included parenthetically, indicating volume and page number; in the present instance - CSM II, 54. CSM provides running references to the standard edition of Descartes's works by Adam and Tannery. 
very clearly and distinctly is true" (CSM II, 24) - and restated in the fifth Meditation as "the mere fact that I can produce from my thought the idea of something entails that everything which I clearly and distinctly perceive to belong to that thing really does belong to it" (CSM II, 45). Descartes seems unaware, however, that the clarity and distinctness rule (at least, as he understood that rule in the Meditations) will not suffice: for while it is arguably true that clear and distinct perceptions guarantee that a given property does belong to a given entity or substance, it does not follow that some other noncontradictory property does not. ${ }^{11}$ Yet this is what is required for the real distinction to hold; otherwise, thought and extension could be properties of the same substance. This is precisely the point upon which Descartes was criticized in, for instance, the second set of Objections. But in the replies to those objections, Descartes merely reiterated the argument of the sixth Meditation. $^{12}$

In the replies to Arnauld in the fourth set of objections, where Arnauld pressed Descartes on the real distinction, Descartes struggled with a subtle point, and it is this struggle which is perhaps the starting point for Malebranche's use of the Meditations. Arnauld had argued that the having of a clear and distinct idea of mind was not sufficient to ensure that mind is distinct from body; his proof of this is that one can have a clear and distinct idea of a right-angled triangle without being aware that the square on the hypotenuse of that triangle is equal to the sum of the squares on the other two

11 There is an ambiguity here which many of Descartes's critics, both past and present, have exploited. The ambiguity is this: we can construe Descartes as arguing that I clearly and distinctly perceive the mind as a thinking thing and I clearly and distinctly perceive the body as an extended thing, that these two clear and distinct perceptions are not identical, and that therefore God can bring it about that the first of these perceptions has an existential counterpart while the other does not (or vice-versa), that is that the two things are really distinct. Or, on the other hand, Descartes could be construed as arguing (as seems obvious given the Cottingham translation) that I have a clear and distinct perception that two things, mind and body, are distinct, and that since whatever I clearly and distinctly perceive is true, these two things are really distinct. But, for the second construal of the argument to be correct, Descartes must at least implicitly be claiming that every clear and distinct idea (and particularly here, the ideas of mind and of body) is completely adequate. For this to be true, one must be aware not only that some property is or is not part of the essence of a thing, but that this awareness includes all properties which form the essence of the thing. Descartes, in the Replies to the Fourth Set of Objections, says explicitly that clear and distinct ideas are not completely adequate. (CSM II, 155-56) If, therefore, the former of the above construals of Descartes's argument is the correct one, it is clear that Descartes does have a problem, for how can I be sure that thought does exclude extension?

12 That is, Descartes merely quotes himself from Meditation VI when it is objected that he has not proved that "a body is incapable of thinking." (CSM II, 94-95) A little later on, in the "Arguments proving the existence of God and the distinction between the soul and the body arranged in geometrical fashion", he gives an argument which differs only in form from that in the Meditations themselves: "God can bring about whatever we clearly perceive in a way exactly corresponding to our perception of it...But we clearly perceive the mind, that is, a thinking substance, apart from the body, that is, apart from an extended substance....And conversely we can clearly perceive the body apart from the mind (as everyone readily admits). Therefore the mind can, at least through the power of God, exist without the body; and similarly the body can exist apart from the mind." (CSM II, 119) 
sides. Thus, one can have a clear and distinct idea without being aware that this idea has consequences of a certain kind; in particular, the mere having of a clear and distinct idea of mind is not enough to show that such an idea excludes the idea of body.

Descartes's response is to argue that the relation which obtains between the concept of the triangle and the property of instantiating the Pythagorean theorem is 1) not a relation obtaining between things, 2) not symmetrical, and 3) not completely independent. That is, the relation in Arnauld's example is between a thing and a property; the relation is asymmetric (i.e. the triangle can be understood without considering the Pythagorean theorem, but the theorem cannot be understood without the notion of a triangle); the triangle must be understood to instantiate some ratio between the sides even if the exact ratio remains unknown. (CSM II, 158) The case of mind and body is supposed by Descartes to be different on each of these counts: the relation is one between two things (the question of their mutual independence aside), it is symmetric (i.e. mind can be conceived without body, and body without mind), and it is independent (i.e. there is no conceptual requirement to construe mind as having some spatial properties, or of body as having some mental properties). The counter-example which Arnauld presents, therefore, is no counter-example at all.

Arnauld's objection, however, forced Descartes to make an important clarification: "But now I must explain how the mere fact that I can clearly and distinctly understand one substance apart from another is enough to make me certain that one excludes the other. The answer is that the notion of a substance is just this - that it can exist by itself, that is, without the aid of any other substance. And there is no one who has ever perceived two substances by means of two different concepts without judging that they are really distinct." (CSM II, 159) For Descartes, there is a crucial distinction to be drawn between the clear and distinct perception of something like a triangle and the clear and distinct perception of something like body or mind, i.e. there is a distinction to be drawn among clear and distinct perceptions, and not just between these perceptions and those which are obscure and confused. The difference which Descartes points to seems akin to a logical difference: we can be aware that a given triangle is right-angled without being aware that it instantiates the Pythagorean theorem, but we cannot be aware that it instantiates the Pythagorean theorem without being aware that it is right-angled. ${ }^{13}$

13 This is not a logical relation, though it may be a legitimate relation in some deontic logic. Both Arnauld and Descartes reject the notion of logical omniscience (i.e. that I am aware of all the consequences of my beliefs); both seem to accept, on the other hand, some notion of consequence or entailment between beliefs or perceptions. 
This shows a dependence relation between the two properties: being rightangled and instantiating the Pythagorean theorem. On the other hand, we can be aware of mind (via, presumably, the properties it exemplifies at a given moment) without being aware of the body (more precisely: without being aware of extension or motion), and vice-versa. The dependence relation found in the triangle case is not present in the mind/body case, therefore mind and body are really distinct. Furthermore, the mind and the body are things, in the plural, because the sets of properties which constitute their individual concepts are unified only on the assumption of substances in which they inhere ${ }^{14}$, and those 'substantial' assumptions do not involve essences which could jointly be dependent on some more basic substance. ${ }^{15}$ Mind and body are therefore really distinct because they are distinct things. Thus, as Descartes sees it, Arnauld's mistake lies in focusing exclusively on the attributive part of the relevant claims from the Meditations (I have a clear and distinct idea of myself as a thinking thing; and I have a clear and distinct idea of the body as an extended thing) to the exclusion of the substantive part (...thinking thing, ,...extended thing). The crucial point here is that, to make the case for the distinction, Descartes invokes an ontological principle-a substance and attribute ontology ordered by dependence - as well as the epistemological rule of clarity and distinctness, and that the argument for the real distinction depends on both of these.

There can be no doubt that Malebranche paid careful attention both to the distinction and to the reasons offered in defense of it. This is apparent most obviously in the manner in which the distinction is introduced in the Search. Only after having discussed the understanding, the will, the nature of judgment and inference, error, sensation and the nature of error arising from sensation, does Malebranche turn to the distinction between soul and body; and when he does so, he prefaces his remarks in this way: "The following matters demand very close attention, for they are of the utmost consequence and are useful in a way quite different from those preceding." (1.10; p. 48) While it is not immediately obvious in what way exactly the distinction between soul and body is to be "useful in a way quite different from" his earlier discussion, the general plan of the Search which occurs in Book one,

14 The above claim is made by Descartes early in the reply: "We do not have immediate knowledge of substances...We know them only by perceiving certain forms or attributes which must inhere in something if they are to exist; and we call the thing in which they inhere a 'substance'." (CSM II, 156)

15 The argument seems to be simply that, once we have arrived at an essence, once a set of properties jointly imply and are singly implied by an essence, we have arrived at a substance, and there is nothing to be gained by proposing a more fundamental substance which would in turn imply two or more essences. At any rate, this is the argument that Malebranche gives for extension as the essence of matter, which he then characterizes as being, i.e. as substance (by contrast to mode). Search, pp. 243-4. 
Chapter four, does provide some direction. There Malebranche says that his aim in general is to detail the kinds of error arising from the various faculties of the soul (following which, he intends to propose "a general method for conducting the search after truth"); his particular aim in Book one is to detail the errors arising from sensation. (1.4.2-3; pp. 17-18) It is in this context that the distinction between soul and body is introduced. Presumably, then, the distinction is useful for getting clear about the errors to which sensation is liable; and this is borne out to some extent by the fact that Chapter ten, in which the distinction is first introduced, ends with a list of "four things we confuse in each sensation", such confusion being "the basis for all other errors of our senses". (1.10.5; p. 52) According to Malebranche, every sensation contains as parts 1) the action of the object which causes it, 2) the passion of the sense organ which transmits it, 3) the perception of the soul, and 4) a judgment about the cause of the sensation. (1.10.6; p. 52) Our natural inclination is to confuse these elements, and this inclination can only be corrected by paying careful attention to the distinction between mind and body.

One would expect, therefore, that Malebranche would be very careful to establish the distinction on the firmest possible grounds, since so much will depend on it. Yet only a very limited argument is provided: "I assume at the outset that the soul can be distinguished from the body by the positive attributes and properties these two substances will admit." (1.10.1; p. 49) Body "is only extension in height, breadth, and depth, and all its properties consist only in (a) motion and rest, and (b) an infinity of different figures. For it is clear: (1) that the idea of extension represents a substance, since one can think of extension without thinking of anything else; (2) this idea can represent only successive or permanent relations of distance, i.e. instances of motion and figure, for one can perceive in extension only what it contains....The soul, on the other hand, is that I in me which thinks, which senses, which wills - it is the substance in which are found all the modifications of which I have an inner sensation, and which subsist only in the soul that perceives them. Thus, no property other than its diverse thoughts should be attributed to the soul. I assume, then, that the soul can be distinguished from the body." (Ibid.) Nowhere here does Malebranche base the distinction on clarity and distinctness; nor does he admit any doubts about the connection between ideas (in particular, the ideas of extension and of motion and figure) which clarity and distinctness would be sufficient to dispel. That is, one does not find Descartes's argument for the distinction between mind and body. However, in this same section, Descartes's Meditations are cited as a source for the distinction, ${ }^{16}$ and crucial components of the argument from the Meditations are present: that the distinction can be made on the grounds of a distinc- 
tion between sets of properties, that the properties in question can be grouped into sets in virtue of the fact that they are unified in substances, and that a dependence relation between a certain property, (extension in the case of body, thought in the case of mind,) and certain subsets of the set of properties of which we are aware (figure and motion in the case of extension, "all the modifications of which I have an inner sensation" in the case of thought ${ }^{17}$ ) is sufficient to establish that the sets implicate distinct substances. In short, Malebranche makes use only of the ontological part of the argument from the Meditations, and ignores the epistemological part altogether. How did Malebranche come to this position?

Malebranche clearly thought that we do not have a clear and distinct idea of the soul: "the reason why all men do not immediately see that colors, odors, tastes, and all other sensations are modifications of their soul is that we have no clear idea of our soul." ${ }^{18}(1.12 .5 ;$ p. 58) Indeed, we have no idea of the soul at all: "neither the soul nor its modifications can be known through ideas...but only by inner sensation." (1.13.4; p. 63) Malebranche cannot, therefore, establish the real distinction between mind and body on the basis of clear and distinct ideas, since according to him one of the requisite ideas is lacking. Besides, as we've just seen, the argument he appeals to when he first introduces the distinction is predicated on "the positive attributes and properties these two substances will admit." Further, Malebranche thought that the Cartesian rule of clarity and distinctness itself rested on a more basic principle, and that therefore it was not, as Descartes had argued, the starting point of all our reasoning. ${ }^{19}$ This is the clearest explanation of why Malebranche came to rely entirely on the ontological part of Descartes's argument for the real distinction. His discussion of the more basic principle is to be found with respect to the other of the two issues that Descartes said had motivated his Meditations, viz., the proof of the existence of God. Malebranche's view is that the ontological argument of Meditations $\mathrm{V}$ stood in need of emendation. Like Malebranche's introduction to Descartes's philosophy, this emendation came via the backdoor.

In Book four of the Search After Truth, Malebranche considers the obs-

16 So are Augustine and Cordemoy, and one would not expect to find in the former anything like the Cartesian argument for the distinction. That is, one would not expect this even if, as has been argued elsewhere, Malebranche's source for Augustine's views was not the original texts but the Cartesian Philosophia christiana of André Martin. See Thomas M. Lennon, The Battle of the Gods and Giants (Princeton: Princeton University Press, 1993), pp. 225-26 for a discussion of this text and Malebranche's use of it.

17 The reason for the difference in the way of referring to the property-sets which attach to body and to mind will, it is hoped, become obvious in what follows below.

18 See also Search, 3.2.7.4; p. 237ff.: "How we know our own soul." References are to the edition and translation by Thomas M. Lennon and Paul J. Olscamp (Cambridge: Cambridge University Press, 1997).

19 See Search 4.11.3; p. 320. 
tacle to the speculative sciences posed by pleasure and sensible qualities generally. As an example, he offers our greater readiness to accept the principle that the whole is larger than its part, which seems confirmed by the senses, than the metaphysical principle on which it actually rests, viz., the Cartesian principle of clarity and distinctness. (P. 316) People fail to see that, because of the priority of this principle, the fact that God exists is no less certain than the principle that the whole is greater than its part. "Here is the first principle [Malebranche's footnote: this reasoning is drawn from Descartes's Meditations]: one should attribute to a thing what one clearly conceives to be included in the idea that represents it; we clearly conceive that there is more magnitude in the our idea of a whole than in our idea of its part;... and that necessary existence is included in the idea we have of God, i.e. in the idea we have of the infinitely perfect being; therefore, the whole is greater than it is parts; ...therefore, God or the infinitely perfect being necessarily exists." (P. 317) Malebranche goes on to offer an elucidation of this proof in terms of his signature theory of the vision of all things in God. When we commonsensically see a finite thing, what we strictly see is its essence, an idea of that thing in the mind of God that represents it. (Hence we commonsensically can see it without it existing.) God cannot be seen in this way because no such finite idea could represent an infinite being; hence "one cannot see God without His existing; one cannot see the essence of an infinitely perfect being without seeing its existence...if one thinks of it, it must exist." (P. 318)

In the fifth edition of Search of 1700, Malebranche provided a clarification of even greater importance. In a long addition to the text, the Cartesian principle of clarity is construed as dependent on an ontological principle that is still more basic. "It is certain that nothingness or the false is not perceptible or intelligible. To see nothing is not to see; to think of nothing is not to think ...nothingness is not perceptible. Properly speaking, this is the first principle of all our knowledge....For the principle generally accepted by the Cartesians, that whatever is clearly conceived to be contained in the idea representing a thing can be asserted of that thing, depends on it." (P. 320) This principle of intentionality, as we may call it, has been taken by André Robinet to be connected with the ontological principal invoked by Descartes in arguing for the real distinction between mind and body, viz. that attributes depend on substance, without which they cannot exist. ${ }^{20}$ Robinet makes the connection by picking up a dialectic sketched earlier by Henri Gouhier. Fully explicating this dialectic would require at least another paper, but the short version 
of it goes as follows. According to Gouhier, in the case of these dependence principles, "human thought is not at the level of essences, but of existence which transcends essences." 21 This is why we can accept, not only the cogito (if there is thinking, there must be a thinker), but also the principle that Descartes invokes in arguing against the void, viz. that nothingness has no attributes, or, if there is an attribute, there must be a substance. ${ }^{22}$ (Indeed, according to Gouhier, not only the former but the latter as well is immune to deception even by the deceiving God of the first Meditation.) It is the ontological import of human thought thus illustrated that grounds the Cartesian credentials of Malebranche's principle of intentionality. Here, the important point is that Malebranche comes finally to dispense with the epistemological principle of clarity and distinctness in favor of an ontological principle that is more basic. As we shall see, Huet agrees with the priority of this principle of intentionality, but for precisely that reason he rejects Descartes's argument for the existence of God.

Pierre-Daniel Huet (1639-1721) tells us in his Memoires that as a youth, before he had studied ancient philosophy, he "belonged for several years, body and soul, to Cartesianism." 23 He also tells us that as a youth he was given instruction in, among other things, dancing and fencing. He says that he was a poor dancer, but excellent in fencing. He does not tell us why, or in what circumstances, he relinquished his Cartesianism and became one of its bitterest, and perhaps most effective, opponents. It might be said, however, that no one fenced with Cartesianism, and ran it through, better than he. ${ }^{24}$

The main work in which Descartes came under attack was the Censura philosophiae cartesianae, first published in 1689, but so well received that it was ready for a fifth edition in 1694. This edition was occasioned by a defense of Descartes by Pierre-Sylvain Regis, the "Prince of the Cartesians," and contains very significant expansions of the more metaphysical parts of the previous editions, which did not differ at all. The upshot was that the work became a censure of "Cartesian" philosophy, not just in the sense relating to its founder, but also to his followers, especially Regis, to an even greater extent that it had been in the earlier version. Huet's reception of the Meditations is therefore best examined by concentrating on that earlier version. ${ }^{25}$

21 La pensée métaphysique de Descartes (Paris: J. Vrin, 1962), p. 291.

22 "It is no less contradictory for us to conceive of a mountain without a valley than it is for us to think of the concavity apart form the extension contained within it, or the extension apart form the substance which is extended; for, as I have said, nothingness cannot possess any extension." Principles, II, 18; CSM II, 230 31.

23 Commentarius (The Hague, 1718), pp. 35-36.

24 Huet also tells us that he was instructed in equitation, and that he was good at it too; but enough of this typically Huetian imago iacosa.

25 First edition: Paris: Horthemels, 1689; fifth edition ("quarta”): Paris: Anisson, 1694. See Germain Malbreil, 
The Censura consists of eight chapters, dealing with 1) the method of doubt and the cogito, 2) the criterion of knowledge, 3) the nature of the mind, 4) the existence of God, 5) body and the void, 6) the origin of the visible world, 7) the cause of gravity, and 8) the Cartesian philosophy in general. Clearly, the topics extend beyond those of the Meditations. As Huet makes clear, however, it is primarily that work which is the object of his criticism. $\mathrm{He}$ is prepared to recognize the value of Descartes's scientific works, especially the Geometry and the Dioptrics, and, to a lesser extent, the Passions of the Soul and the Principles of Philosophy, which he considers largely under the same rubric. The Meteorology he finds weakened by insufficient data, and the Discourse on the Method unobjectionable but also unremarkable. At the "bottom of the list" is the Meditations. "It is possible to judge therefrom that Descartes was especially strong in imagination; his intellect, although vast and sublime, was not of the same rank; and least of all was his judgment, with which he was unable to survey and evaluate the deliverances [inventa] of the other faculties or see their consequences." ${ }^{26}$ Thus, although often cross-referenced to other works by Descartes, most of the Censura in fact deals with the Meditations.

A topic of obvious importance to Huet is the criterion of knowledge. Even more than Malebranche, of course, Huet has no confidence whatsoever in Descartes's reliance on clear and distinct ideas or the natural light whereby they are known. In a sense, all light is natural; or, if not, then we are in no position to draw the distinction; or, if we are, then the natural light can be mistaken, for God can falsify such propositions as 'two plus two make four.' In addition, what is revealed by the natural light ought to be agreed upon by everyone; yet nothing has universal assent, not even one's own existence or humanity, as Democritus and Socrates showed. Huet's conclusion is that clarity and distinctness are neither necessary nor sufficient for truth. They always vary in degree, and thus always leave room for doubt. Moreover, Descartes himself accepted as true what he did not clearly and distinctly perceive, e.g. the infinite divisibility of matter. ${ }^{27}$

The key to Huet's critique is the charge that Descartes does not adhere to his own principles. He claims to doubt everything that can be doubted, but fails in fact to do so, instead substituting his own authority, which he characterizes as indubitable. Moreover, Descartes misunderstands the doubt of the

\footnotetext{
"Descartes censuré par Huet," Revue Philosophique (1991) p. 311, n.2. References here will be to the edition of Kampen: Casper Cotius, 1690, the text of which, though not the pagination, is identical to the first edition, and which is available in an off-print edition - Hildesheim, New York: Georg Olms, 1971.

26 Ibid., pp. 187-88.

27 Censura, ch. 2.
} 
skeptics, who do not doubt for the sake of doubting, but to avoid error, and who have good reasons to be concerned about error that Descartes ignores. Descartes accuses the skeptics of being less than serious, but it is he who is not serious when he gives up doubt at precisely the point at which they would most insist on it. ${ }^{28}$

One way of putting this line of criticism would be to say that Huet was more Cartesian than Descartes himself. A frequent justification offered for departing from Descartes's stated views, especially by self-styled Cartesians, was that they were adhering more closely to the master's most basic principles than he did. ${ }^{29}$ (Thus, when Malebranche rejects the authority of Descartes, his apology is that according to Descartes no one should be regarded as an authority. In other words, he is claiming to be the true believer in Descartes.) In this sense, Huet would be claiming to be the most Cartesian of all. But this way of putting it would also be misleading, for Huet was no skeptic, at least not of the Pyrrhonian sort. The literature from his own time to the present has seen him as a defender of Pyrrhonism, but this is to mistake his antidogmatism for the wrong kind of skepticism. ${ }^{30}$ So much is clear from the Traité philosophique de la faiblesse de l'esprit humain, ${ }^{31}$ published posthumously but written in the same period as the Censura, with which it was intended to form part of a much larger work. ${ }^{32}$ There, Huet is as critical of Pyrrhonism as he is of all other philosophies; what he does not reject, there or anywhere else, is Academic skepticism, which in this period may be understood as nothing more than an anti-dogmatic form of intellectual honesty. Thus, when Huet argues that Descartes does not avoid (Pyrrhonian) skepticism, he is not arguing that (Pyrrhonian) skepticism must therefore be true, but that Descartes's philosophy must be false, the fundamental charge being that Descartes was less than serious and honest.

An important example of Descartes's failure, according to Huet, is his doctrine of the real distinction between mind and body. Here, Descartes is "entirely praiseworthy for his energetic effort at seeking and confirming dogmas that are completely certain for other reasons." ${ }^{33}$ But problems arise because Descartes's efforts are unsatisfactory. "Descartes was so pleased with

28 For more on Huet's critique of Descartes's use of doubt, see Thomas M. Lennon, "Huet on the Reality of Descartes's Doubt," to appear.

29 See Joseph Beaude, "Cartésianisme et anticartésianisme de Desgabets," Studia Cartesiana I (1979).

30 See, e.g., Jean-Paul Dumont, Le scepticisme et le phénomène: essai sur la signification et les origines du pyrrhonisme (Paris: Vrin, 1985 2nd ed.), pp. 55-57. An exception was the abbé J.-B. Flottes, according to whom Huet showed the weakness of reason, not its impotence. Etudes sur Daniel Huet (Montpellier: Seguin, 1857)

31 Amsterdam: H. Du Sauzet, 1723.

32 See Flottes, Ibid., pp.148-49.

33 Censura, ch.3, sec.2. 
himself in these matters that he more than once declared with great show that his thoughts concerning them were his most certain demonstrations, more certain even than geometry, and these thoughts have been received by his votaries with reverence and submission as if they were the pronouncements of the Pythian oracle. I am confident, however, that honest readers will agree that nothing is more worthless or uncertain. So much so that if the knowledge of these dogmas were not perfectly established, as it surely is, there would be reason to fear that what we know to be true on the basis of other, far more certain arguments and the decrees of the holy faith would be called into doubt by incautious men discouraged by the empty proofs of so great a man." ${ }^{34}$ So, while the efforts were praiseworthy, they in fact fail, with the dangerous result that the incautious might be misled into thinking that the dogmas are uncertain. Moreover, dogmatism among the Cartesians entrenches both the failure and the danger. All of this is unnecessary, for the dogmas that Descartes seeks to confirm are already certain "for other reasons," viz. on religious grounds. True belief should be based on faith, the content of which is determined by Scripture and tradition, not on the arrogant pretensions of individuals who regard their own reason as infallible.

Huet tries to upset Cartesian dualism with an argument that he places in the mouth of an Epicurean. More or less following Lucretius, he infers from the undeniable facts of psycho-physical parallelism (such as the fact that a man in a drunken stupor does not think well) that without a body there is no thought. The Epicurean will claim that "what thinks is a man, and that a man is an animated body, sensing and making use of reason, and that wherever, and only wherever, there is a body of this sort, there is a man; ... that a man uses his body in order to think and that thought is either an action of the body or an effect of it, especially since he has often experienced that the use of reason declines when the body is injured or adversely affected, and on the contrary that it thrives when the body is healthy and sound."

Now, Descartes had already in effect answered the Epicurean when he replied to Hobbes that the question of the body is irrelevant to what he has established, viz. that he is a thing that thinks, and that he has different ideas of himself as a thinking thing and of his body. But Huet provides the Epicurean with the following rebuttal. Suppose I hear someone speaking, without knowing anything about this speaking thing other than the fact that it is speaking, not even that it has a body, and that I have different ideas of this thing and of its body. This does not mean that the speaking thing is anything other 
than a body. Here, Descartes cannot reply as he did to Arnauld without begging the question of whether the mind-body connection is a symmetric relation of dependence between things. Descartes's further point that things that are conceivable apart can be separated and hence are different substances is also rebutted by this Epicurean: the question, according to Huet, is not what can happen, but what in fact is the case, i.e. whether there is thought without a body. That is, although there may be no a priori connection between them, thought may yet be a corporeal state, which is an objection to Descartes's dualism still being debated. ${ }^{35}$ That is, the dependence of thought on body, and thus the identity of mind and body, may be empirically discoverable.

Like Malebranche, therefore, Huet finds Descartes's initial reliance on the epistemological principle of clarity to be inadequate. But unlike Malebranche, he sees as useless the deployment of ontological principles that Malebranche was later to invoke in an effort to emend Descartes's position. In particular, as we shall now see, appealing to the intentionality of thought is insufficient. The context is, once again, the proof of the existence of God.

When he turns to Descartes's ontological argument, ${ }^{36}$ Huet first attacks the principle that what is contained in the clear and distinct idea of a thing can be affirmed of that thing. Not only is the principle not indubitable, according to Huet, but it seems false since we clearly and distinctly perceive that lines approaching each other must eventually touch, which is false of a hyperbola and its asymptote. But the "linchpin" of the argument, as he calls it, is the claim that the idea of an infinite and utterly perfect being contains the idea of necessary existence. The claim is true, according to Huet, but it deals only with mental existence, not real existence. "There are two kinds of things: those that depend on the mind, exist nowhere outside it and are obviously fictitious; and those that really exist and are truly part of the order of nature even if no one is thinking of them. In the barbarous language of the schools, the first are said to be only on the side of the intellect, the others on the side of the thing [a parte intellectus...rei]. ${ }^{37}$ Huet's contention is that all our ideas, and a fortiori the idea of God, deal with things only a parte intellectus. To put it another way, that God necessarily exists is only a conception of ours.

Thus, once again, Huet's reception of a key component in Descartes's system is exactly opposite to Malebranche's. For Malebranche, the first principle of all our knowledge is a principle of intentionality: to think is to think 
of something; or, to think of nothing is not to think. Thought guarantees its own object, directly in the case of God, and indirectly for every other object in so far as God is the ground of intelligibility for all else. ${ }^{38}$ For Huet, thought may be opaque and lack intentionality. When commonsensically we think about God, strictly speaking we might be thinking about nothing at all beyond the thought itself.

Huet denounces Descartes for a failure of the very attribute he recommends in order to block the objection, viz. integrity. In his manner of philosophizing, according to Huet, Descartes is not being intellectually honest with himself and certainly not with his readers. Descartes sins against the rules of prudence and modesty in proposing what he takes to be a proof of God's existence which is more cogent than any in mathematics, and which makes anyone impious who does not accept it. "Should Descartes say that the rest of men are ignorant and stupid and that only he is sensible, we shall laugh; for which madman or fanatic will not justify his delusions with a similar response?"39 As Huet put it immediately after ranking the Meditations last in value among Descartes's works, Descartes is so full of himself that he thinks his are arguments as certain as those of geometry, that they cannot contradict theology unless theology itself contradicts reason, that they will bring all dispute to an end, which is ridiculous, as Aristotle pointed out concerning his predecessors' similar claims, and as Cicero pointed out concerning Aristotle's own claim to have ended all disputes. ${ }^{40}$ Moreover, when he himself realizes that his arguments are insufficient, as when he sees that he cannot overcome his hyperbolical doubt, Descartes dissimulates. He says that he only pretends to doubt, for if he admitted to really doubting, he would have to admit that he really did not arrive at certainty. Far from ending philosophical dispute with the ultimate truth, Descartes's philosophy is false and beyond repair, because it based on multiple failures of character.

To conclude, we might point out how very different is Malebranche's attitude. Malebranche defended Descartes's character against the Dutch scholastic Voetius, for example, who, like Huet, accused Descartes of dissimulation. According to Voetius, as Malebranche portrays the accusation, Descartes was "an emissary of the Jesuits with dangerous plots.... [Voetius accuses Descartes] of being an atheist, and even of cunningly and secretly teaching atheism...[who] wrote against atheism only in order to conceal his impiety."

38 This is why Malebranche emends Descartes's ontological argument to read as a simple intuition, rather than as an inference. See Thomas M. Lennon, The Battle of the Gods and Giants, pp. 227-29.

39 Ibid. p. 133, 136.

40 Ibid. p. 188. 
According to Malebranche, however, once Descartes's works are read and meditated upon, Descartes will, far from being accused of atheism, "have all the respect due to a man who has demonstrated in a very simple and evident way... the existence of God and the immortality of the soul ."41 It is because he has this respect for Descartes that Malebranche is prepared to elucidate and emend those demonstrations as he saw necessary.

In summary, we might review the structure of what we have tried to set out. Although it is likely that both Malebranche and Huet initially embraced Descartes's Meditations, they ended by giving this central work very different receptions. Malebranche believed Descartes's intellectual integrity to be such that Christianity was served by emending Descartes's proofs for the existence of God and the immortality of the soul in terms of Descartes's own principles. Huet believed that Descartes's system and his character to be so flawed that Christianity was better served by rejecting his proofs altogether. The opposition between Malebranche and Huet focuses specifically on the ontological principle that to think is to think of something, which Huet rejects, but which Malebranche takes to be the basis of all knowledge.

\section{Bibliografia}

Ferdinand Alquié, Le Cartésianisme de Malebranche (Paris: J. Vrin, 1974).

Yves Marie André, La Vie du R.P. Malebranche (1886) (Genève: Slatkine Reprints, 1970).

Joseph Beaude, "Cartésianisme et anticartésianisme de Desgabets," Studia Cartesiana I (1979).

René Descartes, The Philosophical Writings of Descartes, tr. J. Cottingham, R. Stoothoff, and D. Murdoch (Cambridge: University Press, 1984-85).

Jean-Paul Dumont, Le scepticisme et le phénomène: essai sur la signification et les origines du pyrrhonisme (Paris: Vrin, 1985 2nd ed.).

J.-B. Flottes, Etudes sur Daniel Huet (Montpellier: Seguin, 1857).

H. Gouhier, La pensée métaphysique de Descartes (Paris: J. Vrin, 1962).

A.J. Guibert, Bilbiographie des oeuvres de René Descartes publiées au XVIIe siècle (Paris: Éditions du Centre National de la Recherche Scientifique, 1976).

Pierre-Daniel Huet, Censura Philosophiae Cartesianae, first edition: Paris: Horthemels, 1689; fifth edition ("quarta"): Paris: Anisson, 1694. (off-print edition: Hildesheim: G. Olms, 1971).

Pierre-Daniel Huet, Traité philosophique de la faiblesse de l'esprit humain (Amsterdam: H. Du Sauzet, 1723).

Pierre-Daniel Huet, Commentarius (The Hague, 1718).

41 Search, pp. 293-94. 
Thomas M. Lennon, The Battle of the Gods and Giants (Princeton: Princeton University Press, 1993).

Thomas M. Lennon, "Huet on the Reality of Descartes's Doubt," to appear.

Germain Malbreil, "Descartes censuré par Huet," Revue Philosophique 116 (1991) pp. 311-328.

Nicholas Malebranche, Search after the Truth, tr. Thomas M. Lennon and Paul J. Olscamp (Cambridge: Cambridge University Press, 1997).

André Robinet, Système et existence dans l'oeuvre de Malebranche (Paris: J. Vrin, 1965).

Marleen Rozemond, Descartes's Dualism (Cambridge, Mass.: Harvard University Press, 1998). 